\title{
RELIGIÃO E MIGRAÇÕES
}

HORTA, Ana Paula Beja; PEIXOTO, João. Lisboa: Nova Vega, 2012.

Roberto Marinucci*

Nas últimas décadas cresceu o interesse da comunidade acadêmica em analisar a relação entre migrações e dimensão religiosa. Devido à irrupção de complexas questões religiosas nos debates sócio-políticos internacionais por exemplo, a questão do véu islâmico, dos fundamentalismos, da presença de crucifixos em recintos públicos - percebeu-se a impossibilidade de se compreender corretamente determinadas dinâmicas sociais sem levar em conta a questão religiosa. Nesse âmbito, começou-se também a buscar os nexos entre religióes e mobilidade humana, visando elucidar as recíprocas influências: como as religiões interferem nos fenômenos migratórios e, ao mesmo tempo, como os deslocamentos de pessoas incidem na religiosidade dos migrantes e na estruturação das instituições religiosas.

É nesse contexto geral que deve ser lido o livro Religião e migrações, organizado por João Peixoto, do Instituto Superior de Economia e Gestão da Universidade Aberta de Lisboa, e Ana Paula Beja Horta, do Centro de Estudos das Migrações e das Relações Internacionais, da Universidade Técnica de Lisboa. A obra recolhe contribuições de uma Conferência Internacional ocorrida em Lisboa, nos dias 11 e 12 de julho de 2011, nas instalações do ISEG, sobre o tema "Instituições religiosas e comunidades migrantes - Práticas de intervenção e perspectivas futuras". O evento, organizado por investigadores internacionais e instituições religiosas e cívicas, se insere nas comemorações dos 50 anos (em 2012) da Obra Católica Portuguesa das Migrações (OCPM).

\footnotetext{
* Pesquisador do Centro Scalabriniano de Estudos Migratórios, diretor da Revista REMHU. E-mail: 66robertoro@gmail.com.Brasília/Brasil.
} 
A obra é dividida em duas partes: a primeira apresenta testemunhos, experiências e práticas pastorais da OCPM e de outras instituições religiosas junto a migrantes portugueses ou residentes em Portugal; a segunda inclui textos acadêmicos que, a partir de diferentes enfoques e casos específicos, buscam analisar a relação entre o universo das migrações e a questão religiosa. Nessa ótica, uma riqueza do livro está na articulação entre a dimensão sóciopastoral - alicerçada no contato direito com os migrantes, na busca de boas práticas pastorais e, por vezes, de políticas públicas de promoção de direitos - com a dimensão analítica, que visa uma intelecção do objeto de estudo a partir de pesquisas acadêmicas.

A leitura das diferentes contribuições evidencia, de forma contundente, o intenso e, por vezes, invisível trabalho de grupos, associações ou membros de instituições religiosas numa perspectiva holística, universalista e dialógica: "holística" no sentido que leva em conta o ser humano na sua totalidade, promovendo tanto a dignidade dos migrantes, quanto seu acompanhamento espiritual; "universalista" no sentido que não discrimina ninguém, oferecendo seus serviços independentemente da confissão religiosa do migrante; por fim, "dialógica" na medida em que interpreta o "outro" como interlocutor, como companheiro de caminhada.

Cabe finalmente destacar que, como sinalizado na Introdução, os organizadores da obra não tiveram à disposição os textos escritos de todas as palestras da Conferência, o que os levou a convidar alguns autores para complementar o material para o livro. Dessa forma, podemos dizer que Religião e migrações, antes que "atas" da Conferência, é uma obra realizada "a partir da" Conferência.

O livro é indicado para agentes de pastoral, assistentes sociais e formuladores de políticas imigratórias, bem como para todos aqueles que têm interesse em aprofundar os nexos entre a adesão religiosa e a mobilidade humana. 